\title{
Research and Investigation on English Teachers' Feedback in Classroom and Its Impact on College Learners
}

\author{
Yuhua LI \\ School of Foreign Languages, Wuhan Textile University, Wuhan, 430200, China \\ email: liyuhua1973@sina.com
}

Keywords: College English Teachers; Classroom; Feedback; Learners

\begin{abstract}
English teaching in China places more value on students' cognitive factors than on affective ones. It should be noted that comparatively few studies have been done on affective factors in foreign language acquisition. Therefore, this thesis attempts to explore the features of college English teachers' classroom feedback and its effects on learner's affect with the object to facilitate students, learning and to improve teaching efficiency.
\end{abstract}

\section{Introduction}

At present, China is calling for quality education which claims that teachers at school should center on whole-person development and adopt scientific approach to fully fulfill one's potential and enhance one's all-round qualities. Teachers' feedback is perceived as an indispensable element of teachers' talk. While positive feedback can stimulate students' interest in studies, negative feedback may discourage or demotivate students. [1] Therefore, the study of teachers' feedback is of vital importance to language teaching and learning. Although many researchers home and abroad have done a considerable number of studies on teachers' feedback, few of them focus on the correlation between teachers' feedback and learners' affect. [2]In truth, as an evaluation of students' performance, teachers' feedback can exert a significant impact on students' affective factors like anxiety, self-confidence, attitude, motivation, interest, self-esteem, etc. [3] [4] In view of this, this thesis is to explore the features of college English teachers, classroom feedback and its effects on learners' affect based on Humanistic Education Theory and Krashen's Affective Filter Hypothesis.

The author designed a case study, combining qualitative analysis and quantitative analysis. The subjects involved in the study are non-English major students and their English teacher from Wuhan Textile University. The research instruments consist of classroom observation, questionnaire and interviews. The results obtained from the research are expected to help teachers polish their feedback strategies in a more effective manner. Only when their feedback satisfies the Learners' affective needs is it possible for them to create a non-threatening, comfortable and relaxing learning atmosphere for students.

\section{Theoretical Basis}

The American linguist Stephen Krashen suggested "the Monitor Theory" in 1982 which consists of five hypotheses. [5] They are the Natural Hypothesis, the Input Hypothesis and the Affective Filter Hypothesis, the Acquisition-Learning Hypothesis and the Monitor Hypothesis respectively. Among these five hypotheses, the affective filter is regarded as one of the most important factors in second language acquisition. [6] The filter effect of affective factors in foreign language learning is vividly presented in the following flow chart. 


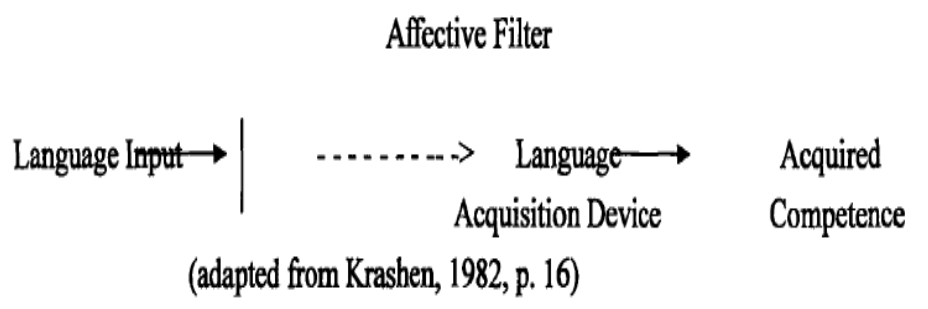

Fig. 1 Affective Filter Hypothesis

According to Krashen (1985), "Comprehensible input is a necessary condition, but it is not sufficient. There can be a mental block that prevents acquirers from fully utilizing the comprehensible input they receive for language acquisition." This block is called "the affective filter". Therefore, Krashen (1985) defined the affective filter hypothesis as "A mental block, caused by affective factors that prevent input from reaching the language acquisition device.” The concept of the filter emphasizes the role for the teacher in creating beneficial conditions for language learning. To put it in another way, teachers are supposed to provide supportive feedback so that students' affective filter is clean enough to more language input. As Krashen mentioned, "motivation, anxiety and self-confidence are significant in constructing the acquired system." The success or failure of learning and teaching largely depends on affective factors (such as motivation, anxiety and self-confidence). Krashen's Affective Filter Hypothesis implies that teachers should create an atmosphere of low affective filter in order to effectively promote students' language acquisition. For another, affect is an essential domain of whole-person development which is parallel to cognition. Humanistic Education Theory places great value on individuals' thoughts, feelings and emotions. So teachers should not only pay attention to students' cognitive development, but also meet their affective needs. Therefore, in structuring the foreign language environment, the teacher needs to be a manager who facilitates language acquisition; an analyst who observes and evaluates what is happening in the classroom; and an adviser who responds to students' answers and motivates their performance. In other words, it is the job of the teacher to help students to boost motivation in their study, to build up self-confidence in their learning capability, and to relieve anxiety in language.

\section{Methodology}

\section{A. Research Questions}

To acquire more detailed information regarding teachers' feedback and students' affect, the present study intends to explore the next two questions;

a. What are the features of teachers' feedback in college English classroom?

b. What is the influence of teachers' feedback on students' affect?

\section{B. Research Subjects}

The subjects of this study involve an English teacher and her students from Wuhan Textile University. All participants are Chinese students. The teacher in this study obtained Master's Degree in Foreign Linguistics and Applied Linguistics and has been teaching English for about four years up to date. There are 168 students from Wuhan Textile University. They are chemistry major freshmen in four different classes labeled as CA, CB, CC, and CD separately.

\section{Data Collection}

A total of 120 students were asked to respond to the questionnaire. They were all required to select one answer from the five choices of each item. However, as some students did not respond to the questions as requested, 105 questionnaires were eventually returned for statistical analysis. The questionnaire is distributed to 120 students from CA, CB, CC and CD. They need to choose one answer from the five options of each item: completely agree, slightly agree, have no idea, slightly disagree, completely disagree. As some question items are not answered by some students, only 105 valid questionnaire surveys are collected eventually. Questionnaire is used as a subsidiary tool to reflect what the teachers' feedback really is from the students' perspective. A survey with a 
questionnaire for students is conducted in order to learn students' expectation towards teachers' feedback. While in the process of statistical analysis, the results of the questionnaire are to describe teachers' feedback accurately and make the research valid. Accordingly, this study is not just a simple description of the data gathered but a process of making explanation about data.

\section{Data Analysis and Findings}

\section{A. Date analysis}

The effectiveness and reliability of a research is largely determined by the quality of data acquisition and data analysis.120 questionnaires were handed out to the students to gain their views regarding their teachers' feedback and 105 valid ones were returned to the author. The results of the questionnaire drawn up from item 1 to item 9 can be found in the following table:

Table 1 The Number and the Proportion of the Options in the Questionnaire

\begin{tabular}{|c|c|c|c|c|c|}
\hline $\begin{array}{c}\text { items } \\
\text { options }\end{array}$ & $\begin{array}{c}\text { completely } \\
\text { agree }\end{array}$ & $\begin{array}{c}\text { slightly } \\
\text { agree }\end{array}$ & $\begin{array}{c}\text { have no } \\
\text { opinion }\end{array}$ & $\begin{array}{c}\text { slightly } \\
\text { disagree }\end{array}$ & $\begin{array}{c}\text { completely } \\
\text { disagree }\end{array}$ \\
\hline 1 & $68 \%$ & $29 \%$ & $3 \%$ & $0 \%$ & $0 \%$ \\
\hline 2 & $2 \%$ & $10 \%$ & $4 \%$ & $16 \%$ & $68 \%$ \\
\hline 3 & $79 \%$ & $16 \%$ & $3 \%$ & $2 \%$ & $0 \%$ \\
\hline 4 & $64 \%$ & $20 \%$ & $7 \%$ & $7 \%$ & $2 \%$ \\
\hline 5 & $81 \%$ & $15 \%$ & $4 \%$ & $0 \%$ & $0 \%$ \\
\hline 6 & $87 \%$ & $7 \%$ & $4 \%$ & $1 \%$ & $1 \%$ \\
\hline 7 & $84 \%$ & $13 \%$ & $3 \%$ & $0 \%$ & $0 \%$ \\
\hline 8 & $95 \%$ & $3 \%$ & $2 \%$ & $0 \%$ & $0 \%$ \\
\hline 9 & $97 \%$ & $2 \%$ & $1 \%$ & $0 \%$ & $0 \%$ \\
\hline
\end{tabular}

From table 1, it is found that $97 \%$ of the students hold the view that the teacher should give a proper response to their answers. Most of them are eager to receive their teacher's feedback after answering questions. 84\% of the students claim that it is not enough for the teacher to just praise them with simple words like "good" or "yes". It shows that they need a concrete comment of their answers rather than simple approval. 95\% of the respondents hope that they can receive the teacher's recognition when their answers are correct. This reflects that the majority of them wish to be accepted be their teacher. More than $80 \%$ of the students agree that they will suffer from loss of confidence and become inactive if their teacher does not respond to their performances.

This data demonstrates that many students need their teacher's caring, which can increase their motivation. The fifth item is about the teacher's criticism. Roughly $96 \%$ of the students hope that their teacher will not criticize them even if they can not answer the teacher's question, while 4\% of the students have no opinion about criticism. Given item 6 and item 7, it can be found that if the students make mistakes in their answers, $87 \%$ of them hope their teacher to give appropriate comments rather than neglecting their mistakes. It is also found that $84 \%$ of them mind their teacher pointing out their errors directly. Evidently, most of the students are very sensitive to their language errors. So the teacher is expected to cope with the students' mistakes carefully and properly.

The questionnaire shows that the majority of the students believe that teacher's feedback plays a crucial part in their language learning. They would like to gain positive feedback, especially approval and praise when they give right answers. Conversely, they do not like criticism or being directly corrected. Additional, most of the students welcome the teacher's non-verbal feedback and hope the teacher to have a better understanding of their affective needs.

\section{B. Learners' Preference to Each Type of Teachers' Feedback}

Through the information obtained from questionnaire, the learners' preference to the teachers, feedback can be summarized as following: From the students' description, it is found that positive feedback which can make them feel relaxed and comfortable is of fundamental importance for their foreign language learning. When talking about the details of positive feedback, they mention that the teacher often makes comments such as "excellent," as a way of evaluation in class. When receiving this kind of evaluation, they are not tense at all and feel positive about themselves. Nonetheless, they say that this simple approval does not satisfy their needs because they hope to get 
a detailed explanation about the answer from the teacher. Plus, the students expect to be encouraged and praised by the teacher because this will stimulate their motivation and increase their self-confidence. When the students are not so sure about the answer, they expect the teacher to help them by giving some hints. When the students can not answer the question, it is found that they would like the teacher to provide further information about the question so that they can have a better understanding about it. When there are mistakes occurring in their answers, most of the students feel that the teacher's pointing out their errors implicitly is easier to be accepted than criticism.

\section{The Influence of Teachers' Feedback on Learners}

According to the outcomes of the student-interview and questionnaires, the majority of students deem that teachers' positive feedback exerts a great impact on their interest, attitude, motivation and self-confidence. Take confidence as an example. The students involved in this study state that teachers' positive feedback increases their self-confident and makes them desire to improve their English. More often than not, the more confident a student feels, the better he will learn. In fact, teachers can help build up students' self-confidence by telling students explicitly that they have faith in their students and by having students make a list of their own merits and accomplishments during the course.

\section{Conclusion}

\section{A. Major findings}

From the analysis of the data gathered from questionnaire, the results of the research questions are found in this paper. Teachers' feedback in college English classroom is generally categorized into two types: positive feedback and negative feedback. The former includes simple approval (or praise), encouragement and expressing thanks whereas the latter consists of indirect correction, direct correction and criticism. Apart from these verbal feedbacks, teachers' non-verbal feedback, such as smile, eye contact and nodding, plays a crucial part in the classroom setting, too. Nearly all the students look forward to positive feedback and dislike negative feedback. Besides, they hope to be encouraged and praised by their teacher as much as possible. With regard to language errors, they welcome indirect correction rather than direct correction or criticism.

\section{B. Pedagogical Implications}

It is important that the teacher creates a friendly and comfortable environment in classroom setting in which students are brave to express themselves and not afraid of making mistakes. Moreover, the teacher plays a critical part in fostering students' determination for success despite difficulties and in giving them the courage to keep making progress. It takes time to build up students' confidence and it initially comes from teachers' own responses to learners' performance, the way they encourage learners and deal with problems together.

\section{Limitations of this Study}

For lacking time, the number of the subjects and the design of the questionnaires is too general to involve all the affective factors. And learners' different language levels should also be well worth of intensive attention in the research. The influence of teachers' feedback may be different for learners with different levels.

\section{Reference}

[1] Brown, H.D. Teaching by Principle, An Interactive Approach to Language Pedagogy [M], New York: Prentice Hall Regents, 1994.

[2] Krashen, S. Principles and Practice in Second Language Acquisition [M]. Oxford: Pergamon Press,1982.

[3] Krashen, S. and T, Terrell. The Natural Approach: Language Acquisition in the Classroom [M]. Oxford: Pergamon Press, 1983. 
[4] Kiashen, S. The Input Hypothesis: Issues and Implications [M]. London: Longman, 1985.

[5] Spielberger, C. Anxiety: Current Trends in Theory and Research [M], New York: Academic Press, 1972.

[6] Williams, M. and R.L. Burden. Psychology for Language Teachers [M]. Beijing: Foreign Language Teaching and Research Press, 2000. 